\title{
Development and validation of Attitude Toward Nutrition Counselling Questionnaire for use among Kuwaiti healthcare professionals
}

Nouf S. Al-Mughamis ${ }^{1 *} \mathbb{0}$, Abdullah A. Alayoub², Hafsa Meraj ${ }^{3}$ and Ahmed Waqas ${ }^{4}$

\begin{abstract}
Objective: This study aims to report the developmental processes and validation of Attitude Toward Nutrition Questionnaire in Arabic language.

Results: A total of 173 (response rate $=86.93 \%)$ participants responded to the survey. There were a total of $92(53.2 \%)$ nutritionists and $81(46.8 \%)$ doctors/surgeons. Principal component analyses revealed followed by visualization of Cattell's scree plot, suggested a four-factor solution for the 36-item Attitude Toward Nutrition Counselling Questionnaire. It was found to have an acceptable validity. These four factors cumulatively explained $37.9 \%$ of the variance in the factor structure of the ATNQ. Cronbach's alpha revealed an acceptable level of reliability for each subscale of the ATNQ. The first subscale named "Factual knowledge about nutrition" comprised of nine items. It yielded a Cronbach's alpha value of 0.78 . The second subscale "knowledge about nutrition in morbidities" comprised of seven items and yielded a Cronbach's alpha value of 0.71 . The third subscale "counselling of patients" comprised of 11 items and yielded a Cronbach's alpha of 0.68 . The fourth subscale comprising nine items yielded a Cronbach's alpha value of 0.64 and was named, "Dietary programs and supplementation".
\end{abstract}

Keywords: Nutrition, Questionnaire, Scale, Knowledge, Dietician, Arabic, Attitude

\section{Introduction}

Nutrition is an essential component of medical care, bearing an association with prognosis, management and outcome of chronic diseases such as coronary and metabolic diseases [1-3]. Therefore, it is crucial for medical professionals to have an adequate knowledge of nutrition in order to improve patient outcomes [4]. Unfortunately, several investigations have shown poor knowledge of nutrition among medical professionals, partly owing to their deficient education during preclinical and clinical training [5-7]. It is, therefore, imperative that nutrition knowledge of practicing medical professionals be assessed to overcome gaps in knowledge and improve patient care [8].

It is important to develop tools and assessment questionnaires pertaining to attitude, knowledge and practices regarding nutrition. However, no such tool has been developed for the middle eastern population of Kuwait. Although an earlier study assessed nutrition knowledge of physicians in Kuwait, a psychometrically valid nutrition knowledge questionnaire has not yet been developed [8]. The present study, therefore, addresses this paucity of data. This study aims to report the developmental processes and validation of Attitude Toward Nutrition Counselling Questionnaire (ATNQ).

\footnotetext{
*Correspondence: almughamisn@gmail.com

${ }^{1}$ Ministry of Health of Kuwait, Kuwait City, Kuwait

Full list of author information is available at the end of the article
}

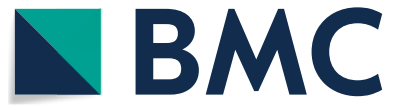

(c) The Author(s) 2020. This article is licensed under a Creative Commons Attribution 4.0 International License, which permits use, sharing, adaptation, distribution and reproduction in any medium or format, as long as you give appropriate credit to the original author(s) and the source, provide a link to the Creative Commons licence, and indicate if changes were made. The images or other third party material in this article are included in the article's Creative Commons licence, unless indicated otherwise in a credit line to the material. If material is not included in the article's Creative Commons licence and your intended use is not permitted by statutory regulation or exceeds the permitted use, you will need to obtain permission directly from the copyright holder. To view a copy of this licence, visit http://creativeco mmons.org/licenses/by/4.0/. The Creative Commons Public Domain Dedication waiver (http://creativecommons.org/publicdomain/ zero/1.0/) applies to the data made available in this article, unless otherwise stated in a credit line to the data. 


\section{Main text \\ Methods \\ Questionnaire development}

The development of the questionnaire was done in a multiphasic process. In the first phase, a thorough review of the literature was conducted to identify the questionnaires and modalities that have been used in the Middle East [9-16]. The items in these questionnaires were then checked for their suitability and adaptation by an experienced dietician and a public health researcher (NS \& AW) inclusion in the ATNQ. In addition, several more items were developed, based upon the Ajzen's theory of Planned Behaviour, which states that an action requires three pre-meditated components; attitudes, knowledge and practice [17]. Overall, these items assessed the participants on attitudes, knowledge and practices related to nutrition and diet in their clinical practice. Responses on these items were assessed using a five-point Likert Scale ranging from strongly agree to strongly disagree.

\section{Pilot survey}

In the next phase, we recruited 18 dieticians, nutritionists $(n=6)$, medical students $(n=3)$ and medical doctors $(n=9)$. The participants were requested to respond to the ATNQ and then comments on its suitability, strengths and weaknesses. Using open ended questions, they were also requested to comment on the items to be excluded or rephrase sentences for an improved comprehension. They were also requested to suggest more items that could be added in the questionnaire. Typical comments raised were to mention measurement units as mmol/l instead of $\mathrm{mg} / \mathrm{dl}$; less suitability of the questionnaire for medical students and a high number of questionnaire items. It was also suggested that questions pertaining to physical activity, renal-nutrition, bariatric surgery, physical activity and knowledge acquisition behaviors be added in the questionnaire. After the pilot study, we made necessary changes in the questionnaire, yielding a total of 52 items in the finalized questionnaire (Table 1). It is important to note that the data collected from the pilot survey was not included in the final dataset.

\section{Data collection}

Based on our preliminary analyses, we expected a two to four factor solution for this questionnaire, where the items presented wide communalities. We judged a sample size of 200 to be adequate for our study based on Comrey and Lee's (1992) recommendation for sample size calculation for factor analysis. They recommended that a sample size of 50 to 100 is poor, 200 is fair, and above 300 is good $[19,20]$. In addition, Mundform et al., recommended a sample size of 55 to 75 participants for scale items presenting with low communalities, two to four factor solution, variable to factor ratio of 12 and a good-level criterion (0.92) [19, 20].

Thereafter, we initiated the cross-sectional survey where a total of 200 dieticians, nutritionists and medical doctors were invited to participant in the survey, using convenient sampling method. Participants were recruited using an electronic survey developed using Survey Monkey platform. Professionals from several institutes and hospitals were contacted to participate in the survey during face to face meetings conducted at the Ministry of Health in Kuwait. Before participating in the survey, all the participants signed informed consent forms. Participation in the survey was voluntary, anonymous and the participants could leave the study at any time. Average time for completion of the questionnaire was around $20 \mathrm{~min}$. Ethical approval for this study was provided by Ethical Review Board of Ministry of Health of Kuwait, Kuwait.

All data were analyzed using the SPSS v.25. Firstly, the data was subjected to dimension reduction using the Principal Component Analysis (PCA) and orthogonal rotation [18]. This process ascertained the dimensionality of the questionnaire by guiding the number of factors to retain and redundant items to be excluded. Before running the PCA, its suitability was assessed using the Kaiser-Meyer-Olkin (KMO) sampling adequacy statistic $(>0.60)$ and Bartlett's test of sphericity. Number of factors to retain was based on three criteria; variance explained by each factor, Eigen value $>1$ and the Cattell's Scree Plot. Naming of each factor retained was done subjectively by analyzing the theme of most items included in the questionnaire. Suitability of each item was assessed using several criteria. For each item to be suitable for inclusion in the final scale, it was ensured that the KMO sampling adequacy value was $>0.6$ for each item in the anti-image of the covariance matrix; communality value was $\geq 0.2$ and the factor loading was $\geq 0.32$.

Reliability analysis was done to evaluate the internal consistency of the overall scale, where a value $\geq 0.60$ as considered to be acceptable [21]. Convergent validity was assessed using the Pearson's correlation indices obtained using the inter-item correlations. Moreover, contribution to the overall Cronbach's alpha value yielded by the scale was also assessed.

\section{Results}

\section{Demographics}

A total of 173 (response rate $=86.93 \%$ ) participants responded to the survey. There was a total of $92(53.2 \%)$ nutritionists and $81(46.8 \%)$ doctors/surgeons. Mean scores on individual items ranged from $1.99(\mathrm{SD}=1.12)$ for item seven (BMI value $>18.5$ is considered to be 
Table 1 Rotated component matrix showing dimensionality of the Attitude Toward Nutrition Counselling Questionnaire

Statements

ncreased intake of fruits and vegetables is associated with good blood pressure control

A traditional Mediterranean diet focuses on a reduction in total fat intake

Research has shown strong evidence that Atkin's low carbohydrate diet regime leads to a good cardiovascular health

In comparison with nutrition, proper exercise is more important in reduction of cardiovascular risk factors

I have been trained in important dietary guidelines including US Dietary Agency's Guidelines for adults

Unsaturated fatty acids are healthier than saturated fatty acids

A BMI value $>18.5$ is considered to be overweight among young adults

A high caffeine intake can lead to increased heart rate and anxiety

Folic acid supplements should be started in third trimester of pregnancy

Calcium supplementation is not important for patients with osteoporosis

US dietary guidelines recommend less than 2 servings of dairy products per day for an adult

US dietary guidelines recommend between 6 and 11 servings of grain based products per day for an adult

Patients with diabetes should be prescribed a diet with a low glycemic index to improve their blood sugar levels

Meat products have the highest vitamin B-12 levels

Vegetable oil has higher trans-fats than hydrogenated oils

Women should have adequate exposure to sunlight to aid in vitamin D synthesis in their bodies

Lower hemoglobin levels in blood may be due to poor levels of potassium in diet

There are around 20 essential amino acids that are synthesized in human body and do not have to be taken from outside source

Bariatric surgery is a good treatment option for patients with extremely high BMI $(>40)$

It is important to refer most of my patients with obesity to nutritionists for expert advice

I believe that a balanced nutrition is important for prevention of diseases including cardiovascular (atherosclerosis) and metabolic (diabetes mellitus) diseases

Taking CME courses in nutrition in dietetics enhance my clinical practice, and management of patients

Nutritionists are an important part of inter-disciplinary healthcare teams in hospitals

It is important to calculate BMI and waist to hip ratio among my patients, to assess risk for cardiovascular diseases.

Weight loss dietary regimens such as Atkin's diet are poor for health

I recommend specific diets (DASH, Mediterranean, Ketogenic etc.) in my clinical practice

I am adequately trained to impart nutrition related counselling to patients

I routinely prescribe green vegetable consumption to patients with kidney stones In my clinical practice, I routinely prescribe iron supplements to anemic mothers

I routinely perform nutrition related physical examinations to calculate BMI, waist to hip ratio and muscle mass among my patients

I follow non-peer reviewed blogs to gain information on nutrition

Factors

Factual

knowledge

Morbidities

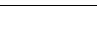

0.558

0.362

0.479

$-0.344$

0.614

0.412

0.410

0.407

0.349

0.335

0.385

0.3

0.368

0.705

0.819

0.849

0.480

0.672 
Table 1 (continued)

\begin{tabular}{|c|c|c|c|c|}
\hline \multirow[t]{2}{*}{ Statements } & \multicolumn{4}{|l|}{ Factors } \\
\hline & $\begin{array}{l}\text { Factual } \\
\text { knowledge }\end{array}$ & Morbidities & $\begin{array}{l}\text { Counselling } \\
\text { of patients }\end{array}$ & $\begin{array}{l}\text { Dietary programs } \\
\text { and supplementation }\end{array}$ \\
\hline $\begin{array}{l}\text { Serum triglyceride levels between } 1.8 \text { and } 2.2 \mathrm{mmol} / / \mathrm{l}(150 \text { to } 199 \mathrm{mg} / \mathrm{dL}) \text { are } \\
\text { considered in a very high range }\end{array}$ & & & 0.473 & \\
\hline $\begin{array}{l}\text { I routinely recommend high fibres diets to my patients, presenting with bowel } \\
\text { problems }\end{array}$ & 0.339 & & & \\
\hline $\begin{array}{l}\text { For guidance related to nutrition, I use authentic sources such as text books, } \\
\text { Medscape and up-to-date }\end{array}$ & 0.484 & & & \\
\hline
\end{tabular}

overweight) to $4.70(\mathrm{SD}=0.50)$ for item 29 (referring patients with obesity to nutritionists).

\section{Factor validity}

The KMO measure of sampling adequacy was found to be adequate at 0.71 (Bartlett's test of sphericity $\mathrm{P}<0.001$ ). Each statement had demonstrated an adequate KMO value $(\geq 0.60)$ in anti-image of correlation matrix. The factors to retain were assessed using several criteria. The criteria of Eigen value $>1$ suggested that at least 11 factors should be retained. An assessment of the variance explained by the factor structure of the ATNQ showed that only four factors explained the highest proportion of variance. The Cattell's scree plot suggested that only four factors be retained with the Eigen values ranging from
4.23 for factor to 2.85 for factor 4 (Fig. 1). These four factors cumulatively explained $37.9 \%$ of the variance in the factor structure of the ATNQ (Table 2).

Principle component analysis suggested that 16 items including item $4,11,18,23,28,36,39,40,41$ and 44 cross-loaded strongly on two factors. And items $5,8,13,19,35$ and 52 had lower factor loading $<0.30$ (Additional file 1: Table S1). These items were removed from the final scale. Among the 36 remaining items (Table 2), the highest communality was shown by item 25 while communalities $<0.20$ were exhibited by several statements including item 2 , 12, 15, 20 and 50. However, these were not excluded and were kept for further assessment. All the items had an adequate communality $\geq 0.30$. Highest factor loading was 0.85 demonstrated by statement 25 ,

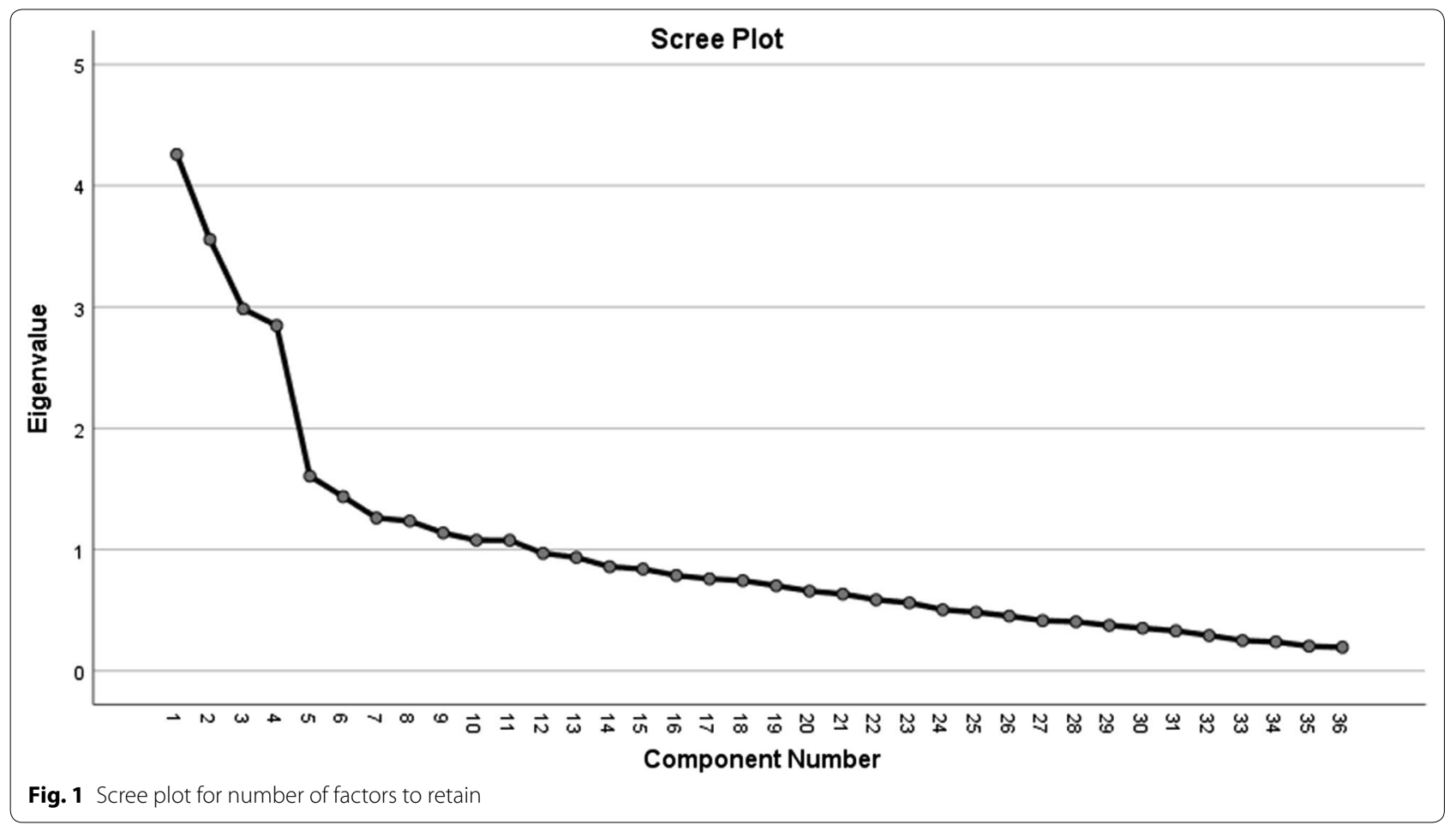


Table 2 Reliability statistics

\begin{tabular}{|c|c|c|c|c|c|}
\hline Item & $\begin{array}{l}\text { Scale mean } \\
\text { if item } \\
\text { deleted }\end{array}$ & $\begin{array}{l}\text { Scale variance } \\
\text { if item deleted }\end{array}$ & $\begin{array}{l}\text { Corrected } \\
\text { item-total } \\
\text { correlation }\end{array}$ & $\begin{array}{l}\text { Squared } \\
\text { multiple } \\
\text { correlation }\end{array}$ & $\begin{array}{l}\text { Cronbach's alpha } \\
\text { if Item deleted }\end{array}$ \\
\hline $\begin{array}{l}\text { Increased intake of fruits and vegetables is associated with } \\
\text { good blood pressure control }\end{array}$ & 115.6347 & 109.787 & 0.225 & 0.308 & 0.684 \\
\hline $\begin{array}{l}\text { A traditional Mediterranean diet focuses on a reduction in } \\
\text { total fat intake }\end{array}$ & 116.5509 & 108.357 & 0.216 & 0.244 & 0.684 \\
\hline $\begin{array}{l}\text { Research has shown strong evidence that Atkin's low carbo- } \\
\text { hydrate diet regime leads to a good cardiovascular health }\end{array}$ & 117.1796 & 110.666 & 0.123 & 0.376 & 0.690 \\
\hline $\begin{array}{l}\text { In comparison with nutrition, proper exercise is more } \\
\text { important in reduction of cardiovascular risk factors }\end{array}$ & 116.3713 & 114.994 & -0.084 & 0.351 & 0.708 \\
\hline $\begin{array}{l}\text { I have been trained in important dietary guidelines includ- } \\
\text { ing US Dietary Agency's Guidelines for adults }\end{array}$ & 116.5988 & 105.651 & 0.284 & 0.480 & 0.679 \\
\hline $\begin{array}{l}\text { Unsaturated fatty acids are healthier than saturated fatty } \\
\text { acids }\end{array}$ & 115.5988 & 109.675 & 0.201 & 0.242 & 0.685 \\
\hline $\begin{array}{l}\text { A BMI value }>18.5 \text { is considered to be overweight among } \\
\text { young adults }\end{array}$ & 117.7305 & 109.367 & 0.153 & 0.309 & 0.689 \\
\hline $\begin{array}{l}\text { A high caffeine intake can lead to increased heart rate and } \\
\text { anxiety }\end{array}$ & 115.4611 & 111.997 & 0.101 & 0.244 & 0.691 \\
\hline $\begin{array}{l}\text { Folic acid supplements should be started in third trimester } \\
\text { of pregnancy }\end{array}$ & 117.6347 & 105.438 & 0.328 & 0.355 & 0.676 \\
\hline $\begin{array}{l}\text { Calcium supplementation is not important for patients with } \\
\text { osteoporosis }\end{array}$ & 115.7425 & 114.192 & -0.044 & 0.366 & 0.701 \\
\hline $\begin{array}{l}\text { US dietary guidelines recommend less than } 2 \text { servings of } \\
\text { dairy products per day for an adult }\end{array}$ & 117.0838 & 115.041 & -0.081 & 0.282 & 0.702 \\
\hline $\begin{array}{l}\text { US dietary guidelines recommend between } 6 \text { to } 11 \text { serv- } \\
\text { ings of grain based products per day for an adult }\end{array}$ & 116.2515 & 109.720 & 0.217 & 0.287 & 0.684 \\
\hline $\begin{array}{l}\text { Patients with diabetes should be prescribed a diet with a } \\
\text { low glycemic index to improve their blood sugar levels }\end{array}$ & 115.7006 & 111.488 & 0.119 & 0.296 & 0.690 \\
\hline Meat products have the highest vitamin B-12 levels & 115.8802 & 111.648 & 0.070 & 0.336 & 0.694 \\
\hline Vegetable oil has higher trans-fats than hydrogenated oils & 116.9281 & 101.441 & 0.445 & 0.628 & 0.665 \\
\hline $\begin{array}{l}\text { Women should have adequate exposure to sunlight to aid } \\
\text { in vitamin } D \text { synthesis in their bodies }\end{array}$ & 117.2814 & 101.276 & 0.430 & 0.674 & 0.666 \\
\hline $\begin{array}{l}\text { Lower hemoglobin levels in blood may be due to poor } \\
\text { levels of potassium in diet }\end{array}$ & 116.9820 & 101.283 & 0.469 & 0.704 & 0.664 \\
\hline $\begin{array}{l}\text { There are around } 20 \text { essential amino acids that are synthe- } \\
\text { sized in human body and do not have to be taken from } \\
\text { outside source }\end{array}$ & 117.1078 & 113.012 & 0.011 & 0.346 & 0.697 \\
\hline $\begin{array}{l}\text { Bariatric surgery is a good treatment option for patients } \\
\text { with extremely high BMI }(>40)\end{array}$ & 117.4731 & 106.504 & 0.289 & 0.513 & 0.679 \\
\hline $\begin{array}{l}\text { It is important to refer most of my patients with obesity to } \\
\text { nutritionists for expert advice }\end{array}$ & 115.0299 & 111.848 & 0.209 & 0.623 & 0.687 \\
\hline $\begin{array}{l}\text { I believe that a balanced nutrition is important for preven- } \\
\text { tion of diseases including cardiovascular (atherosclerosis) } \\
\text { and metabolic (diabetes mellitus) diseases }\end{array}$ & 115.0599 & 112.057 & 0.161 & 0.600 & 0.688 \\
\hline $\begin{array}{l}\text { Taking CME courses in nutrition in dietetics enhance my } \\
\text { clinical practice, and management of patients }\end{array}$ & 115.2814 & 109.637 & 0.268 & 0.522 & 0.682 \\
\hline $\begin{array}{l}\text { Nutritionists are an important part of inter-disciplinary } \\
\text { healthcare teams in hospitals }\end{array}$ & 115.0838 & 114.089 & -0.011 & 0.512 & 0.694 \\
\hline $\begin{array}{l}\text { It is important to calculate BMI and waist to hip ratio } \\
\text { among my patients, to assess risk for cardiovascular } \\
\text { diseases }\end{array}$ & 115.2335 & 108.698 & 0.330 & 0.427 & 0.679 \\
\hline $\begin{array}{l}\text { Weight loss dietary regimens such as Atkin's diet are poor } \\
\text { for health }\end{array}$ & 115.9880 & 108.446 & 0.239 & 0.431 & 0.683 \\
\hline $\begin{array}{l}\text { I recommend specific diets (DASH, Mediterranean, } \\
\text { Ketogenic etc.) in my clinical practice }\end{array}$ & 116.0599 & 103.611 & 0.426 & 0.416 & 0.669 \\
\hline $\begin{array}{l}\text { I am adequately trained to impart nutrition related counsel- } \\
\text { ling to patients }\end{array}$ & 116.2515 & 109.021 & 0.167 & 0.547 & 0.688 \\
\hline
\end{tabular}


Table 2 (continued)

\begin{tabular}{|c|c|c|c|c|c|}
\hline Item & $\begin{array}{l}\text { Scale mean } \\
\text { if item } \\
\text { deleted }\end{array}$ & $\begin{array}{l}\text { Scale variance } \\
\text { if item deleted }\end{array}$ & $\begin{array}{l}\text { Corrected } \\
\text { item-total } \\
\text { correlation }\end{array}$ & $\begin{array}{l}\text { Squared } \\
\text { multiple } \\
\text { correlation }\end{array}$ & $\begin{array}{l}\text { Cronbach's alpha } \\
\text { if Item deleted }\end{array}$ \\
\hline $\begin{array}{l}\text { I routinely prescribe green vegetable consumption to } \\
\text { patients with kidney stones }\end{array}$ & 116.8802 & 105.684 & 0.360 & 0.293 & 0.674 \\
\hline $\begin{array}{l}\text { In my clinical practice, I routinely prescribe iron supple- } \\
\text { ments to anemic mothers }\end{array}$ & 116.4611 & 108.889 & 0.208 & 0.393 & 0.685 \\
\hline $\begin{array}{l}\text { I routinely perform nutrition related physical examinations } \\
\text { to calculate BMI, waist to hip ratio and muscle mass } \\
\text { among my patients }\end{array}$ & 116.3832 & 108.623 & 0.200 & 0.476 & 0.685 \\
\hline $\begin{array}{l}\text { I follow non-peer reviewed blogs to gain information on } \\
\text { nutrition }\end{array}$ & 116.7365 & 101.689 & 0.464 & 0.431 & 0.664 \\
\hline $\begin{array}{l}\text { I am confident in prescribing lipid lowering agents such } \\
\text { as statins for patients with cardiovascular risk factors and } \\
\text { diseases }\end{array}$ & 116.3174 & 107.989 & 0.174 & 0.589 & 0.688 \\
\hline $\begin{array}{l}\text { For patients with metabolic risk factors, I routinely calculate } \\
\text { risk algorithms such as the Framingham Risk score or the } \\
\text { Reynold Risk score }\end{array}$ & 116.9042 & 110.870 & 0.096 & 0.499 & 0.693 \\
\hline $\begin{array}{l}\text { Serum triglyceride levels between } 1.8 \text { and } 2.2 \mathrm{mmol} / \mathrm{l}(150 \\
\text { to } 199 \mathrm{mg} / \mathrm{dL} \text { ) are considered in a very high range }\end{array}$ & 116.9760 & 109.698 & 0.169 & 0.298 & 0.687 \\
\hline $\begin{array}{l}\text { I routinely recommend high fibers diets to my patients, } \\
\text { presenting with bowel problems }\end{array}$ & 117.1557 & 111.409 & 0.078 & 0.353 & 0.694 \\
\hline $\begin{array}{l}\text { For guidance related to nutrition, I use authentic sources } \\
\text { such as text books, Medscape and up-to-date }\end{array}$ & 117.5749 & 109.704 & 0.171 & 0.267 & 0.687 \\
\hline
\end{tabular}

while the lowest communality was 0.34 by item 6 . Item \# 20 was removed from the overall scale at this point because it had shown a lower factor loading as well as communality.

\section{Reliability statistics}

The Cronbach's alpha based on standardized items was 0.69 for the 36-item scale. Each item in the scale had at least one inter-item correlation $\geq 0.20$, exhibiting appropriate convergent validity. Removing Item 6 (In comparison with nutrition, proper exercise is more important in reduction of cardiovascular risk factors) from the overall scale, improved the Cronbach's alpha value to 0.71 . In addition, an assessment of Cronbach's alpha value of individual subscales revealed acceptable internal consistency. The first subscale named "Factual knowledge about nutrition" comprised of nine items. It yielded a Cronbach's alpha value of 0.78 . The second subscale "knowledge about nutrition in morbidities" comprised of seven items and yielded a Cronbach's alpha value of 0.71 . The third subscale "counselling of patients" comprised of 11 items and yielded a Conrbach's alpha of 0.68 . The fourth subscale comprising nine items yielded a Cronbach's alpha value of 0.64 and was named, "Dietary programmes and supplementation".

\section{Known group analysis}

Total scores on the finalized scale were compared among physicians/surgeons and dieticians and nutritionists. The latter group scored higher on the scale (mean $=121.55$, $\mathrm{SD}=16.62)$ than the former $($ mean $=115.83, \mathrm{SD}=8.90)$. And this difference was found to be statistically significant.

\section{Discussion}

This is the first study from Kuwait to report the development and validation of Attitude Toward Nutrition Counselling Questionnaire. It comprises of 36 items divided into four scales namely: (a) factual knowledge about nutrition; (b) knowledge about nutrition in morbidities; (c) counselling of patients and (d) dietary programmes and supplementation. This scale was found to have an acceptable reliability and validity.

During the development phase of the questionnaire, the original version comprised of 52 items. Several of these items were removed during the validation phase. For instance, item 4, 11, 18, 23, 28, 36, 39, 40, 41, 44 were removed because they exhibited strong factor loading on two different factors. While item 5, 8, 13, 19, 35 and 52 exhibited low factor loadings. These items weakened the construct validity of the questionnaire and therefore, were not included in the modified 35 item scale. Moreover, during the face validity period a few items 
were reworded. For instance, units for several metabolic parameters were changed from $\mathrm{mg} / \mathrm{dL}$ to $\mathrm{mmol} / \mathrm{L}$ that is more prevalent in medical practice. A few of the physicians also noted difficulty in understanding US dietary guidelines, however, these questions were kept in the questionnaire because no alternative guidelines were available for the Kuwaiti population.

\section{Limitations}

This study has several strengths. An appropriate sample size was used for this study that comprised healthcare professionals across several specialties. It showed excellent internal consistency and validity among both the nutritionists and physicians and surgeons. This scale has several practical implications. It can be used to assess knowledge and attitudes of nutrition among doctors and assess areas/topics where training is required. It can thus, help to develop, tailor and tweak educational intervention packages for doctors. It can also be used to conduct pre and post assessment studies after delivery of an educational intervention regarding nutrition.

\section{Supplementary information}

Supplementary information accompanies this paper at https://doi. org/10.1186/s13104-020-4905-9.

Additional file 1: Table S1. Rotated Component Matrix for the original 52 item scale.

\section{Abbreviations}

PCA: Principal Component Analysis; KMO: Kaiser-Meyer-Olkin; ATNQ: Attitude Toward Nutrition Counselling Questionnaire.

\section{Acknowledgements}

None.

\section{Authors' contributions}

NS and AA conceived the idea of the study, collected the data and wrote initial draft of the manuscript. AW analyzed the data, interpreted it and critically reviewed and edited the manuscript. HM revised the manuscript. All authors read and approved the final manuscript.

\section{Funding}

This study has not received any funding.

\section{Data availability}

The dataset associated with this study, is available on request from the corresponding author.

\section{Ethics approval and consent to participate}

Ethical approval was granted by the Ministry of Public Health, Kuwait. All members provided with written informed consent and voluntarily participated in the study.

\section{Consent for publication}

Not applicable.

\section{Competing interests}

The authors report that they have no conflict of interests to declare. Dr. Ahmed Waqas serves BMC Research Notes as an associate editor, however, the editorial and review process was conducted independent of his involvement.

\section{Author details}

${ }^{1}$ Ministry of Health of Kuwait, Kuwait City, Kuwait. ${ }^{2}$ Kuwait Cancer ControlMinistry of Health of Kuwait Center, Shuwaikh, Kuwait. ${ }^{3}$ Shifa College of Medicine, Islamabad, Pakistan. ${ }^{4}$ University of Liverpool, Liverpool, UK.

Received: 16 October 2019 Accepted: 14 January 2020

Published online: 07 February 2020

\section{References}

1. Nishida C, Uauy R, Kumanyika S, Shetty P. The joint WHO/FAO expert consultation on diet, nutrition and the prevention of chronic diseases: process, product and policy implications. Public Health Nutr. 2004;7(1a):245-50.

2. Kromhout D, Menotti A, Kesteloot H, Sans S. Prevention of coronary heart disease by diet and lifestyle: evidence from prospective cross-cultural, cohort, and intervention studies. Circulation. 2002;105(7):893-8.

3. Baute V, Sampath-Kumar R, Nelson S, Basil B. Nutrition education for the health-care provider improves patient outcomes. Global Adv Health Med. 2018;7:2164956118795995.

4. Mogre V, Stevens FC, Aryee PA, Amalba A, Scherpbier AJ. Why nutrition education is inadequate in the medical curriculum: a qualitative study of students' perspectives on barriers and strategies. BMC Med Educ. 2018;18(1):26.

5. Abdollahi M, Houshiarrad A, Abtahi M, Esmaeli M, Pouraram H, Khoshfetrat MR, Shakori MM, Keshel SH. The nutrition knowledge level of physicians, nurses and nutritionists in some educational hospitals. J Paramed Sci. 2013;13:4.

6. Allafi AR, Alajmi F, Al-Haifi A. Survey of nutrition knowledge of physicians in Kuwait. Public Health Nutr. 2013;16(7):1332-6.

7. Mowe M, Bosaeus I, Rasmussen HH, Kondrup J, Unosson M, Rothen-

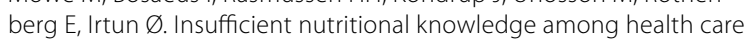
workers? Clin Nutr. 2008;27(2):196-202.

8. Trakman GL, Forsyth A, Hoye R, Belski R. Developing and validating a nutrition knowledge questionnaire: key methods and considerations. Public Health Nutr. 2017;20(15):2670-9.

9. Al-Numair KS. Nutrition knowledge of primary care physicians in Saudi Arabia. Pak J Nutr Sci. 2004;3:344-7. https://doi.org/10.3923/ pjn.2004.344.347.

10. Al-Zahrani AM, Al-Raddadi RM. Nutritional knowledge of primary health care physicians in Jeddah, Saudi Arabia. Saudi Med J. 2009:30:284-7.

11. Al-Muammar MN. Predictors of physicians' practices related to nutritional counseling and management in Riyadh City. Alex J Med. 2012;48:67-74. https://doi.org/10.1016/j.ajme.2011.09.002.

12. Allafi AR, Alajmi F, Al-Haifi A. Survey of nutrition knowledge of physicians in Kuwait. Public Health Nutr. 2013;16:1332-6. https://doi. org/10.1017/s1368980012003606.

13. Dumic A, Miskulin M, Pavlovic N, Orkic Z, Bilic-Kirin V, Miskulin I. The nutrition knowledge of Croatian General Practitioners. J Clin Med. 2018;7:178. https://doi.org/10.3390/jcm7070178.

14. Park KA, Cho WI, Song KJ, Lee YS, Sung IS, Choi-Kwon SM. Assessment of nurses' nutritional knowledge regarding therapeutic diet regimens. Nurse Educ Today. 2011;31:192-7. https://doi.org/10.1016/j. nedt.2010.05.017.

15. Bradulskis S, Adamonis K, Cicènienè J, Kutkevičius J, Sutkutè A, Birgiolaitè E, et al. A survey of medical students' and doctors' knowledge of nutritional correction. Liet Chir. 2014. https://doi.org/10.15388 /lietchirur.2014.1.2948.

16. Alkaed D, Ibrahim N, Ismail F, Barake R. Validity and reliability of a Nutrition Knowledge Questionnaire in an adult student population. J Nutr Educ Behav. 2018;50:718-23. https://doi.org/10.1016/j. jneb.2018.03.012.

17. Ajzen I. The theory of planned behavior. Organ Behav Hum Decis Process. 1991;50:179-211. https://doi.org/10.1016/0749-5978(91)90020 -t.

18. Suhr DD. Principal component analysis vs. exploratory factor analysis. SUGI 30. 2005. http://www2.sas.com/proceedings/sugi30/203-30.pdf. 
19. Mundfrom DJ, Shaw DG, Ke TL. Minimum sample size recommendations for conducting factor analyses. Int J Test. 2005;5(2):159-68.

20. Comrey AL, Lee HB. A first course in factor analysis. Hillsdale: Lawrence Eribaum Associates. Inc., Publishers; 1992.

21. Streiner DL. Starting at the beginning: an introduction to coefficient alpha and internal consistency. J Pers Assess. 2003. https://doi. org/10.1207/s15327752jpa8001_18.

\section{Publisher's Note}

Springer Nature remains neutral with regard to jurisdictional claims in published maps and institutional affiliations.
Ready to submit your research? Choose BMC and benefit from:

- fast, convenient online submission

- thorough peer review by experienced researchers in your field

- rapid publication on acceptance

- support for research data, including large and complex data types

- gold Open Access which fosters wider collaboration and increased citations

- maximum visibility for your research: over $100 \mathrm{M}$ website views per year

At BMC, research is always in progress.

Learn more biomedcentral.com/submissions 